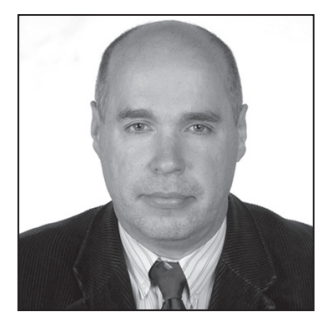

Jaan Ginter

Professor of Criminology

University of Tartu

\title{
The Survival of Retributivism in our Modern Knowledge-based World
}

In retributivism, one strives to justify criminal punishment simply by referring to the punishment as the consequence that the criminal plainly deserves and arguing that there is no need to present any utilitarian justifications for applying punishments. At present, more and more research results are mounting up that suggest various objective circumstances as causes for predisposition of certain persons to commit crimes, and some research suggests that there are several treatments that may in some cases be more suitably employed instead of criminal punishments. With this paper, I undertake to appraise whether these novel approaches leave any room for retributivist ideas.

\section{The long and venerable history of retributivist thinking}

As long as societies have held that certain actions by members of society should be averted and have punished their members for these actions, societies also have tried to find means of rationalising the accordant intentional causing of psychological, physical, and material losses to members thereof. For example, the Code of Hammurabi, which dates back to the eighteenth century BC, offers a fundamentally retributivist view:

196. If a man put out the eye of another man, his eye shall be put out.

197. If he break another man's bone, his bone shall be broken. ${ }^{* 1}$

We can find many references to retributivism in the Torah and the Old Testament. For example, in the Old Testament, the third book of the Pentateuch, Leviticus, states that ' $[\mathrm{w}]$ hoever takes a human life shall surely be put to death. Whoever takes an animal's life shall make it good, life for life. If anyone injures his neighbor, as he has done it shall be done to him, fracture for fracture, eye for eye, tooth for tooth; whatever injury he has given a person shall be given to him. Whoever kills an animal shall make it good, and whoever kills a person shall be put to death' (24:17-21). ${ }^{{ }_{2}}$ And the second book of the Pentateuch, Exodus, states: 'But if

1 Yale Law School's Avalon Project. Translation of the Code of Hammurabi, available at http://avalon.law.yale.edu/ancient/ hamframe.asp (most recently accessed on 24.1.2017).

2 Leviticus 24, English Standard Version, available at http://biblehub.com/esv/m/leviticus/24.htm (most recently accessed on 25.1.2017). 
there is harm, then you shall pay life for life, eye for eye, tooth for tooth, hand for hand, foot for foot, burn for burn, wound for wound, stripe for stripe' $(21: 23-25){ }^{*}{ }^{*}$

Retributivism is highly appreciated in Hegelian and Kantian philosophy. The Kantian approach is fairly straightforward:

Punishment by a court - this is distinct from natural punishment, in which vice punishes itself and which the legislator does not take into account - can never be inflicted merely as a means to promote some other good for the criminal himself or for civil society. It must always be inflicted upon him only because he has committed a crime. For a man can never be treated merely as a means to the purposes of another or be put among the objects of rights to things: His innate personality protects him from this, even though he can be condemned to lose his civil personality. He must previously have been found punishable before any thought can be given to drawing from his punishment something of use for himself or his fellow citizens. The principle of punishment is a categorical imperative, and woe to him who crawls through the windings of eudaemonism in order to discover something that releases the criminal from punishment or even reduces its amount by the advantages it promises [...]. But what kind and what amount of punishment is it that public justice makes its principle and measure? None other than the principle of equality (in the position of the needle on the scale of justice), to incline no more to one side than to the other. Accordingly, whatever undeserved evil you inflict upon another within the people, that you inflict upon yourself. If you insult him, you insult yourself; if you steal from him you steal from yourself; if you strike him, you strike yourself; if you kill him, you kill yourself. ${ }^{* 4}$

For Kant, a person is an autonomous moral agent and, therefore, crimes are a reflection of wilful deliberation, not merely illicit harms resulting from undeliberated drives or emotions. Nor are crimes signs of a need for therapy, a 'bad attitude', or of recalcitrance. For the Kantian retributivist, even the fact of an individual wilfully committing a particular kind of crime repeatedly is not, by itself, an indication that the crimes were acts of compulsion or that the criminal is incorrigible. ${ }^{*}$

Hegel starts his rationalisation of punishments pretty much from the same locus as Kant. For him, '[t] he threat presupposes that human beings are not free, and seeks to coerce them through the representation [Vorstellung] of an evil. But right and justice must have their seat in freedom and the will, and not in that lack of freedom at which the threat is directed. To justify punishment in this way is like raising one's stick at a dog; it means treating a human being like a dog instead of respecting his honour and freedom'. ${ }^{* 6}$ But 'Hegel imports consequentialist considerations into the determination of actual punishments'. ${ }^{* 7} \mathrm{He}$ has stated that '[i]f society is still inwardly unstable, punishments must be made to set an example, for punishment is itself a counter-example to the example of crime'. ${ }^{* 8}$ Hence from the Hegelian standpoint, the punishment for concrete offences may depend on such circumstances as the state of the society in which those penalties are disbursed. ${ }^{*}{ }^{9}$

Completely contradicting these views are ideas proposed by the utilitarian or consequentialist camp. For instance, Jeremy Bentham stated that 'all punishment is mischief: all punishment in itself is evil. Upon the principle of utility, if it ought at all to be admitted, it ought only to be admitted in as far as it promises to exclude some greater evil'. ${ }^{*} 10$

3 Exodus 21, English Standard Version, available at http://biblehub.com/esv/m/exodus/21.htm (most recently accessed on 25.1.2017).

4 M.J. Gregor (ed.). Kant: The Metaphysics of Morals. Cambridge University Press 1996, 6:332. - DOI: https://doi. org/10.1017/cbo9780511809644.

5 J.L. Anderson. Annulment retributivism: A Hegelian theory of punishment. - Legal Theory 5 (1999), on p. 366. - DOI: https://doi.org/10.1017/s1352325299054014.

6 G.W.F. Hegel. Elements of the Philosophy of Right (Allen W. Wood, editor). Cambridge: Cambridge University Press 1991, on pp. 125-126. Book available at http://www.inp.uw.edu.pl/mdsie/Political_Thought/Hegel\%20Phil\%20 of\%20Right.pdf (most recently accessed on 29.1.2017).

7 J. Johnson. Hegel on punishment: A more sophisticated retributivism. - Mark D. White (ed.). Retributivism: Essays on Theory and Policy. Oxford: Oxford University Press 2011, pp. 146-168, on p. 157. - DOI: https://doi.org/10.1093/acpro f:oso/9780199752232.003.0009.

$8 \quad$ G.W.F. Hegel (see Note 6), p. 251.

9 J. Johnson (see Note 7), p. 158.

10 J. Bentham, An Introduction to the Principles of Morals and Legislation. Kitchener, Ontario: Batoche Books [1781] 2000, p. 134. 
In contemporary discussion, retributivism and consequentialism are still in fierce rivalry in the quest for being the main rationalisation for punishment and have left alternative rationalisations (e.g., communication $^{{ }^{* 11}}$ or restorative justice ${ }^{{ }^{* 12}}$ ) peripheral.

The Estonian Penal Code takes a unifying approach, and its Section 56 states that '[p]unishment shall be based on the guilt of the person. In imposition of a punishment, a court or a body conducting extrajudicial proceedings shall take into consideration the mitigating and aggravating circumstances, the possibility to influence the offender not to commit offences in the future, and the interests of the protection of public order. ${ }^{*}{ }^{13}$ That is, '[t]he system is built on a certain punishment theoretical conception under which the extent of guilt determines the maximum punishment while other criteria rule the determination of the lowest punishment - the danger posed by the act to society and the prevention'. ${ }^{* 14}$

According to the Ken Levy classification scheme, the Estonian Penal Code follows weak retributivism. Levy posits that ' $[t]$ here are two kinds of retributivism: weak and strong. Weak retributivism says that just deserts is a necessary condition of criminal punishment, that criminal punishment cannot be just unless the person punished committed criminal wrongdoing and is being punished for that wrongdoing. Strong retributivism says that just deserts (criminal wrongdoing) is a sufficient condition of criminal punishment, that criminal punishment should always be inflicted for criminal wrongdoing. ${ }^{\prime} 15$

Today we have to acknowledge that there have emerged two new strong lines of argument against retributivism:

A. we are finding more and more situations wherein we can ascertain objective foundations for human actions, leaving less room for free will and just deserts, and

B. we are finding more and more situations in which we are able to use alternative rehabilitative measures instead of traditional criminal punishments.

\section{Whether our will is free enough to substantiate retribution}

Let us look at some cases that have brought that question up for wide discussion.

In August 1966, 'Charles Whitman took an elevator to the top floor of the University of Texas Tower in Austin. The 25-year-old climbed the stairs to the observation deck, lugging with him a footlocker full of guns and ammunition [...]. By the time the police shot him dead, Whitman had killed 13 people and wounded 32 more'. ${ }^{* 16}$ If Whitman had not been shot down with fatal effect, he would most likely have been convicted for multiple murder and the retributivists would have been convinced that the punishment constituted just deserts and was justified even if no utilitarian aim had been achieved.

Police officers found a suicide note that Whitman had written the night before the massacre, requesting his autopsy. ${ }^{*}{ }^{17}$ An autopsy was indeed performed after this, and it revealed a brain tumour pressing against his amygdala, a part of the brain associated with fear and aggression. ${ }^{*} 18$

11 A.Y.K Lee. Defending a communicative theory of punishment: The relationship between hard treatment and amends. - Oxford Journal of Legal Studies 37 (2017) / 1. - DOI: https://doi.org/10.1093/ojls/gqw003.

12 T. Brooks. Punishment. New York: Routledge 2012, pp. 67, 212.

13 The Estonian Penal Code as amended by RT I, 31.12.2016, 2; RT I 2001, 61, §364 and §692, available at https://www. riigiteataja.ee/akt/131122016014?leiaKehtiv (most recently accessed on 20.2.2017). In the English language at https:// www.riigiteataja.ee/en/eli/519012017002/consolide (most recently accessed on 20.2.2017).

$14 \mathrm{~J}$. Sootak. Theories of punishment and reform of criminal law (reform as a change of mentality). - Juridica International 2000, p 73, available at http://www.juridicainternational.eu/public/pdf/ji_2000_1_68.pdf (most recently accessed on 5.2.2017)

15 K. Levy. Why retributivism needs consequentionalism: The rightful place of revenge in the criminal justice system. - Rutgers Law Review 66 (2014) / 3, pp 645-646, available at http://docplayer.net/37238789-Why-retributivism-needs-consequentialism-the-rightful-place-of-revenge-in-the-criminal-justice-system.html (most recently accessed on 27.2.2017).

16 D. Eagleman. The brain on trial. - Atlantic Monthly 2011/ June-July, available at http://www.theatlantic.com/magazine/ archive/2011/07/the-brain-on-trial/308520/ (most recently accessed on 1.8.2017).

17 Charles Whitman suicide note, from 31 July 1966, available from Alt.CIMedia.com at http://alt.cimedia.com/statesman/ specialreports/whitman/letter.pdf (most recently accessed on 2.2.2017).

18 D. Eagleman (see Note 16). 
In contemplating Whitman's case, we cannot be sure that if we had managed to discover and remove his tumour earlier, the University of Texas tragedy of 1966 would not have happened. In any case, however, the results of the autopsy suggest that there could have been a substantial objective foundation that contributed to the otherwise unexplainable fatal decision.

But there have been other, much clearer cases. Shortly after turning 40, Michael developed a strong interest in child pornography. This was followed by a conviction for child molestation after Michael was found to have inappropriately fondled his 12-year-old stepdaughter. At the time of sentencing, the judge gave Michael the option of avoiding jail by entering a treatment programme. Anxious to avoid jail, Michael took up the offer. While in the programme, Michael acted inappropriately toward female members of staff. He complained of headaches the night before he was supposed to be sentenced, having failed the treatment programme and been ejected from it. An MRI scan was ordered because he showed frank neurological as well as behavioural signs in the neurological consulting room. The MRI revealed a large orbitofrontal tumour. Once the tumour was removed, Michael's bad behaviour ceased, his sexual urges toward children disappeared, and he successfully completed his programme. Several months after he returned home, Michael's urges resurfaced. Medical examination revealed that the tumour too had returned. After the tumour was again removed, the urges ceased and Michael remained a free man. ${ }^{*} 19$

In this case, it is pretty clear that without the double surgery Michael would have ended up in prison serving his sentence and that this would have been considered without hesitations a just desert.

It is possible that some true retributivist could defend retributivism from the setback posed by such cases, suggesting that these are cases of insanity. In neither of the cases was the insanity defence tested. Therefore, it is not possible to show how such a defence would have been assessed by a court, but, although in both cases there was a clear medical condition that contributed to commission of the crime, there was no sign that the medical condition deprived the accused of the ability to distinguish right from wrong or made him incapable of controlling his behaviour at the time of the offence. Hence, an insanity defence would most likely have been denied.

Of course, only a very small percentage of criminals have had a brain tumour that contributed towards their commission of the crime. But there are other studies, which show that the likelihood of future crimes can be substantially influenced by much more widespread objective distinctive features of the person's genetics or brain activity.

In 2014, one study revealed why Whitman's behaviour may have been linked to the tumour beside his amygdala: that research indicated that lower amygdala volume in men is associated with childhood aggression, early psychopathic traits, and violence. ${ }^{{ }_{20}}$ It had already been revealed that there is a connection between early-childhood impaired fear conditioning (suggesting retarded maturation of the amygdala) and adult crime. ${ }^{{ }^{2} 1}$

There have been various genetic studies as well. For example, a (MAO-A) gene in combination with childhood maltreatment has been reported to be associated with a significantly increased risk of antisocial behaviour. ${ }^{* 22}$

By using functional magnetic resonance imaging (fMRI), it is possible to locate regions of the brain that are active during emotional and intellectual activity. One study focused on inmates who were about to be released from jail. In the study, they were instructed to press a button as quickly as possible whenever an ' $\mathrm{X}$ ' appeared on the screen ( $84 \%$ occurrence probability) but not when a ' $\mathrm{K}$ ' was displayed (16\% occurrence probability). By using fMRI, the researchers tracked activity in the anterior-cingulate cortex (ACC) - a part of the limbic lobe associated with impulse control - during the exercise. They found that offenders who showed low ACC activity during the exercise were arrested twice as often within four years of release as offenders with high ACC activity. Furthermore, ACC activity was a better recidivism predictor than other

19 J.M. Burns, R.H. Swerdlow. Right orbitofrontal tumor with pedophilia symptom and constructional apraxia sign. - Archives of Neurology 60 (2003) / 3, pp. 437-440. - DOI: https://doi.org/10.1001/archneur.60.3.437.

20 D.A. Pardini. Lower amygdala volume in men is associated with childhood aggression, early psychopathic traits, and future violence. - Biological Psychiatry 75 (2014), pp. 73-80. - DOI: https://doi.org/10.1016/j.biopsych.2013.04.003.

21 Y. Gao et al. Association of poor childhood fear conditioning and adult crime. - The American Journal of Psychiatry 167 (2010), pp. 56-60. - DOI: https://doi.org/10.1176/appi.ajp.2009.09040499.

22 A. Caspi et al. Role of genotype in the cycle of violence in maltreated children. - Science 297 (2002) / 5582, pp. 851-854. DOI: https://doi.org/10.1126/science.1072290; D.L. Foley et al. Childhood adversity, monoamine oxidase A genotype, and risk for conduct disorder. - Archives of General Psychiatry 61 (2004), pp. 738-744. - DOI: https://doi.org/10.1001/ archpsyc.61.7.738. 
factors, among them age at release, substance abuse, task-error rate, and psychopathy score. Hence, the authors suggested ACC haemodynamic activity as a potential neurocognitive biomarker of persistent antisocial behaviour, at least at the group level. ${ }^{{ }_{2} 23}$

Studies have pointed to inadequacies in the frontal cortex of the offender's brain. ${ }^{* 24} \mathrm{~A}$ meta-analysis including all prefrontal and prefrontal sub-regional findings indicated that antisocial individuals showed reduced structure or function in the prefrontal cortex. ${ }^{* 25}$

Clearly, brain scans may be used in sentencing proceedings to identify and support claims of lesser culpability due to circumstances beyond the control of the offender that could have a mitigating effect on the sentence. ${ }^{*}{ }^{26}$ Today a multifaceted criminal defence using MAO-A genotyping and neuroimaging has already been introduced in criminal cases and occasionally even accepted in court judgements as a mitigating circumstance. ${ }^{* 27}$ Also, 'it is likely that neuroscience will discover evidence of brain disorders that will expand the definition of excuse or add to the list of accepted excuses [...]. It may be that in the future, we treat conditions such as psychopathy and pedophilia more as psychiatric disorders than as criminal conduct'. ${ }^{* 28}$

The possible influence of research results from neuroscience on the domain of law has led to an enormous increase in the number of research publications on this topic. There were not many publications in this field before 2000. In the early years of this millennium, there were still fewer than 100 publications a year on the topic, but since 2012 the number has been consistently over 1,00o annually, and it is still growing. ${ }^{* 2}$ An equivalent tendency has been seen in introducing expert testimony on neuroscience and behavioural genetics in criminal trials in the United States; since 2010, hundreds of judicial opinions discussing neurobiological issues introduced by/for criminal defendants have accumulated each year. ${ }^{*}{ }^{30}$

The more evidence is gathered on objective foundations for commission of offences, the more difficulties there will be in persuasion that punishment can be rationalised as a just desert that has to be employed without consideration as to whether there is any utilitarian effect present.

\section{How far we should substitute treatment for punishment}

There are many circumstances wherein societies have found there to be more sense in applying treatment instead of (quite often even more costly) criminal punishment. And if it makes sense to substitute treatment for criminal punishment, no room remains for theorising that punishment is a just desert.

The idea of coercing drug users into treatment is not new. In the United States the idea can be traced back to the 'narcotic farms' of the 1920 and 1930s. These farms treated not only genuine volunteers with no prior engagement in criminal activity, but also offenders who were offered treatment in lieu of punishment [...]. In Australia, coerced treatment of drug offenders has constituted

23 E. Aharoni et al. Neuroprediction of future rearrest. - Proceedings of the National Academy of Sciences of the United States of America 110 (2013), pp. 6223-6228. - DOI: https://doi.org/10.1073/pnas.1219302110.

24 A. Raine et al. Reduced prefrontal gray matter volume and reduced autonomic activity in antisocial personality disorder. Archives of General Psychiatry 57 (2000), pp. 119-127. - DOI: https://doi.org/10.1001/archpsyc.57.2.119.

25 Y. Yang, A. Raine. Prefrontal structural and functional brain imaging findings in antisocial, violent, and psychopathic individuals: A meta-analysis. - Psychiatry Research: Neuroimaging 174 (2009), pp. 81-88. - DOI: https://doi.org/10.1016/j. pscychresns.2009.03.012.

26 E. Bennett. Neuroscience and criminal law: Have we been getting it wrong for centuries and where do we go from here? Fordham Law Review 85 (2016), p. 449, available at http://fordhamlawreview.org/wp-content/uploads/2016/11/Bennett_November-1.pdf (most recently accessed on 5.2.2017).

27 E. Feresin. Lighter sentence for murderer with 'bad genes'. - Nature, 30 October 2009. - DOI: https://doi.org/10.1038/ news.2009.1050; William Bernet et al. Bad nature, bad nurture, and testimony regarding MAOA and SLC6A4 genotyping at murder trials. - Journal of Forensic Science 52 (2007) / 6, pp. 1362-1371. - DOI: https://doi.org/10.1111/j.15564029.2007.00562.x.

28 E. Bennett (see Note 26).

29 M.A. Fozdar. The relevance of modern neuroscience to forensic psychiatry practice. - Journal of the American Academy of Psychiatry and the Law Online 44 (2016) / 2, p. 146, available at http://jaapl.org/content/44/2/145.full.pdf (most recently accessed on 6.2.2017).

30 N.A. Farahany. Neuroscience and behavioral genetics in US criminal law: An empirical analysis. - Journal of Law and the Biosciences, Advance Access Publication of 14 January 2016, pp. 485-509. - DOI: https://doi.org/10.1093/jlb/lsv059. 
a popular alternative to incarceration for about 40 years. And a number of other countries have more recently adopted similar initiatives [...]. Another group of offenders, particularly relevant in relation to the discussion of rehabilitative treatment as an alternative to imprisonment, is that of sex offenders. Several types of treatment exist which aim at either curing paraphilic disorders or at controlling their manifestations [...]. The final group of offenders that should be mentioned is that of violent criminals. Several types of rehabilitative treatment - including, first and foremost, different forms of cognitive behavioural therapy - have for some time been offered to offenders suffering from explosive violent temperaments. ${ }^{*}{ }^{31}$

More recently, attention has been drawn to new types of treatment. Some research indicates that it is possible to reduce the risk of offending by employing various nutritional supplements - e.g., simple omega-3 in the diets of risk-prone persons. ${ }^{*}{ }^{32}$ In addition, there have already been some more complex attempts to address predispositions to offence and find alternatives to penal punishment. The Cognitive Centre of Canada, at the University of Ottawa ${ }^{*} 33$, has worked for decades in this direction and offered some prospective methods for the prevention and treatment of antisocial behaviour. ${ }^{*} 34$

In the Estonian Penal Code (the EPC), there is enshrined an option that allows substitution of treatment for imprisonment in certain cases. This is possible if imprisonment of six months up to two years is imposed on a person for an act committed because of a treatable or controllable mental disorder, with that person's written consent. Still, only two courses of treatment are allowed to be employed:

1) treatment of drug addicts for addiction, used for a person who has committed a criminal offence for reason of drug addiction

2) complex treatment of adult sex offenders, for a person who has committed a criminal offence because of sexual-orientation disorder ${ }^{*} 35$

With these constraints taken into account, the EPC would not allow applying substitution for imprisonment by way of treatment in the above-mentioned case of Michael, in which the necessary treatment was brain surgery.

Nonetheless, the EPC would not be completely powerless to offer some relief in a case such as Michael's. The EPC allows a court to order suspension of the sentence on probation, and one of the obligations that the court may impose on the offender for the duration of supervision of conduct is to undergo the prescribed treatment if the offender has previously consented to said treatment. ${ }^{*} 6$

Nevertheless, it is feasible that, sooner or later, the list of applicable courses of treatment should be amended. There is, for example, a growing list of treatment programmes applicable to reduce aggressive behaviour ${ }^{*} 37$, and it would be unwise to assume that science is incapable of finding additional human predispositions to criminal activities that can be treated.

It is unrealistic to offer a concrete prediction as to how far substitution of treatment for punishment will advance, but there are research-based estimates that a large percentage of criminals have psychiatric issues. One study concluded that almost two thirds of US jail inmates have a mental health problem. ${ }^{*} 8$

31 J. Ryberg. Is coercive treatment of offenders morally acceptable? On the deficiency of the debate. - Criminal Law and Philosophy 9 (2015) / 4 (December), pp. 621-624. - DOI: https://doi.org/10.1007/s11572-013-9288-8.

32 A. Zaalberg et al. Effects of nutritional supplements on aggression, rule-breaking, and psychopathology among young adult prisoners. - Aggressive Behavior 36 (2010), pp. 117-126. - DOI: https://doi.org/10.1002/ab.20335.

33 See http://www.cognitivecentre.ca/ (most recently accessed on 14.2.2017).

34 S.J. Young, R.R. Ross. R\&R2 for ADHD Youths and Adults: A Prosocial Competence Training Program - Program Handbook. Ottawa: Cognitive Centre of Canada 2007, p. 162, available via https://www.academia.edu/9330842/R_and_R2_for_Youths_and_Adults_with_ADHD (most recently accessed on 16.2.2017); R.R. Ross, D.H. Antonowicz. Antisocial Drivers: Prosocial Driver Training for Prevention and Rehabilitation. Springfield, Illinois: Charles C Thomas 2004.

35 Estonian Penal Code, $\S 69^{2}$.

$36 \quad \mathrm{EPC}, \S \S 74$ and 75.

37 L. Brännström et al. Aggression replacement training (ART) for reducing antisocial behavior in adolescents and adults: A systematic review. - Aggression and Violent Behavior 27 (2016) / March-April, pp. 30-41. - DOI: https://doi.org/10.1016/j. avb.2016.02.006; C. Balia et al. The pharmacological treatment of aggression in children and adolescents with conduct disorder. Do callous-unemotional traits modulate the efficacy of medication? - Neuroscience \& Biobehavioral Reviews, available online from 27 January 2017. - DOI: https://doi.org/10.1016/j.neubiorev.2017.01.024.

38 K.D. Kim et al. The Processing and Treatment of Mentally Ill Persons in the Criminal Justice System: A Scan of Practice and Background Analysis. Urban Institute, March 2015, p. 8, available at http://www.urban.org/sites/default/files/ publication/48981/2000173-The-Processing-and-Treatment-of-Mentally-Ill-Persons-in-the-Criminal-Justice-System.pdf (most recently accessed on 21.2.2017). 
Hence, neuroscience may be able to offer many new trustworthy treatments for persons having a criminal predisposition.

For example, there is a large amount of research into possible social effects of the neuropeptide oxytocin. Oxytocin became very attractive as a research topic after it was revealed that simple intranasal administration of it increases generosity by $80 \% .{ }^{*}{ }^{39}$ The first attempts to employ the neuropeptide in therapy for diverse social phobias, mood disorders, and other personality disorders have already emerged. ${ }^{*} 4$

\section{Conclusions}

The mounting research results attesting to objective foundations for criminal actions and opportunities to respond to a criminal act not by applying a criminal punishment but by rendering treatment leave less and less room for retributivist and just-deserts arguments. The more that science is able to understand why certain people commit criminal offences and is able to find opportunities to treat these conditions, the less need there will be to think of punishments as just deserts that simply have to be applied without a search for any utilitarian justification.

It is already evident that the strong retributivism claim that 'criminal punishment should always be inflicted for criminal wrongdoing ${ }^{*} 41$ is incompatible with the practice of replacing punishment with treatment, a practice that is spreading today.

There is still room for the weak retributivism assertion that 'criminal punishment cannot be just unless the person punished committed criminal wrongdoing and is being punished for that wrongdoing. ${ }^{*}{ }^{42}$ But the more capable science becomes of reliably detecting predispositions to commit criminal offences and of designing dependable measures to reverse these predispositions, the less space there will be even for weak retributivism. Modern societies are unanimously convinced that in certain circumstances strong measures may be applied with regard to persons who are a substantial threat to other persons without looking for any deserts - serious contagious diseases and mental health problems are routinely handled in a manner employing measures that restrict human rights no less than imprisonment does and much more than do other criminal punishments, such as pecuniary sanctions.

39 P.J. Zak et al. Oxytocin increases generosity in humans. An Open Access article published on 7 November 2007. - DOI: https://doi.org/10.1371/journal.pone.0001128. The research measured the generosity-implying ultimatum game (UG), which is routinely employed for this task in economics experiments. In the UG, person A is endowed with $\$ 10$ and asked to make an offer on how to split this money between persons A and B, where person B has no endowment. If B accepts the split, the money is paid out as A has decided. If B does not accept the split, no-one receives any money. See, for example, A.G. Sanfey et al. The neural basis of economic decision-making in the ultimatum game. - Science 300 (2003) / 5626, pp. 1755-1758. - DOI: https://doi.org/10.1126/science.1082976.

40 N. Striepens. Prosocial effects of oxytocin and clinical evidence for its therapeutic potential. - Frontiers in Neuroendocrinology 32 (2011), pp. 426-450. - DOI: https://doi.org/10.1016/j.yfrne.2011.07.001.

41 K. Levy (see Note 15)..

42 Ibid. 